\title{
KEBIJAKAN PENETAPAN PEMERINTAHAN KAMPUNG ADAT DI KABUPATEN SIAK PROVINSI RIAU
}

Oleh :

\author{
MUAMMAR ALKADAFI \\ (Dosen Prodi Administrasi Negara, Fakultas Ekonomi dan Ilmu Sosial, UIN Suska Riau) Email : \\ alkadafi.amar@gmail.com \\ RUSDI \\ (Dosen Prodi Administrasi Negara, Fekonsos, UIN Suska Riau. Email:_fahrudi_alqowi@yahoo.co.id) \\ FITRIA RAMADHANI AGUSTI NST \\ (Dosen Prodi Administrasi Negara, Fekonsos, UIN Suska Riau Email : fitriaramadhaninst@yahoo.com) \\ MUHAMMAD APRIL \\ (Dosen Prodi Administrasi Perpajakan, Fekonsos, UIN Suska Riau. Email : april.aap@gmail.com)
}

\begin{abstract}
Abstrak
Keberadaan pemerintahan desa, desa adat atau nama lain, melalui konstitusi dan Undang-Undang Nomor 6 tahun 2014 memberikan pengakuan dan jaminan terhadap keberadaan kesatuan masyarakat hukum dan kesatuan masyarakat hukum adat beserta hak tradisionalnya. Pemerintahan Kampung adat yang ditetapkan oleh pemerintah Kabupaten Siak merupakan perwujudan dari pengakuan tersebut, tujuan penetapan kampung adat di kabupaten siak ialah untuk menghidupkan kembali peranan tokoh adat dalam penyelenggaraan pemerintahan, pembangunan dan pelayanan kepada masyarakat. Tujuan penelitian. Untuk mengetahui proses penetapan, pelaksanaan asal usul dalam penyelenggaraan pemerintahan dan faktor penghambat. Metode penelitian. lokasi dan fokus pada Kampung Adat Kampung Tengah, Lubuk Jering, Kuala Gasib dan Sakai Bekalar. Sumber data ialah data primer dan sekunder, diperoleh melalui observasi, wawancara, dokumentasi, studi kepusatakaan. Selanjutnya, data yang diperoleh dianalisis secara kualitatif, dan diuji dengan triangulasi untuk mengambil suatu kesimpulan.

Hasil penelitian mengungkapkan, proses kebijakan penetapan perubahan status Kampung menjadi kampung adat di Kabupaten Siak belum dilakukan kajian secara komprehensif, sehingga secara prosedur dalam penetapan kebijakan belum memenuhi beberapa aspek yang diatur dalam ketentuan peraturan perundang-udangan. Penetapan peraturan daerah kabupaten siak nomor 2 tahun 2015 tentang kampung adat secara administratif belum terpenuhi, nomor registrasi dari gubernur riau tentang kampung adat belum dikeluarkan dan kode kampung adat dari kementerian dalam negeri juga belum dikeluarkan. Dengan demikian, pelaksanaan asal usul dan adat istiadat dalam penyelenggaraan pemerintahan belum terlaksana, dikarenakan masih dibutuhkan regulasi lanjutan untuk mengimplementasikannya, Peraturan Daerah Provinsi Riau tentang pangaturan susunan kelembagaan dan pengisian jabatan perangkat kampung adat belum dikeluarkan. Faktor penghambat dalam pelaksanaan ialah kampung adat yang ditetapkan belum memenuhi keseluruhan syarat administrasi dalam penetapannya, regulasi pendukung untuk mengoperasionalkan penyelenggaraan pemerintahan berdasarkan hukum adat dan susunan asli belum ada. Adat istiadat tidak lagi terpelihara dengan baik, tokoh-tokoh adat di Masyarakat sudah berkurang, eksistensi kelembagaan adat tidak berfungsi di masing-masing Kampung Adat yang telah ditetapkan .
\end{abstract}

Kata Kunci: Kebijakan, Penetapan, Pelaksanaan, Pemerintahan Kampung Adat 


\section{Pendahuluan}

Kedudukan desa dalam paradigma yang baru tidak hanya menempatkan desa sebagai organisasi pemerintahan yang berada dalam sistem pemerintahan kabupaten/kota (local state goverment), tetapi juga menempatkan desa sebagai organisasi campuran (hybrid) antara masyarakat berpemerintahan (self governing community) dengan pemerintahan lokal (local self goverment). ${ }^{1}$

Pada penjelasan pasal 18 Undang-Undang Dasar Negara Republik Indonesia Tahun 1945 (sebelum perubahan) poin II menyebutkan bahwa "dalam territoir Negara Indonesia terdapat lebih kurang 250 "Zelfbesturende landschappen" dan "Volksgemeenschappen", seperti desa di Jawa dan Bali, Nagari di Minangkabau, dusun dan marga di Palembang, dan sebagainya. Daerah-daerah itu mempunyai susunan Asli dan oleh karenanya dapat dianggap sebagai daerah yang bersifat istimewa. Negara Republik Indonesia menghormati kedudukan daerah-daerah istimewa tersebut dan segala peraturan negara yang mengenai daerah-daerah itu akan mengingati hak-hak asal usul daerah tersebut". Oleh sebab itu, keberadaannya wajib tetap diakui dan diberikan jaminan keberlangsungan hidupnya dalam Negara Kesatuan Republik Indonesia. ${ }^{2}$ UUD 1945 Pasal 18B ayat 2, menyebutkan Negara mengakui dan menghormati kesatuankesatuan masyarakat hukum adat beserta hak-hak tradisionalnya sepanjang masih hidup dan sesuai dengan perkembangan masyarakat dan prinsip Negara Kesatuan republik Indonesia, yang diatur dalam Undang-undang. ${ }^{3}$ dari aturan konstitusional tersebut, mengharuskan negara melakukan rekognisi (pengakuan dan penghormatan) terhadap kesatuan masyarakat hukum adat yang ada di Indonesia sperti (desa, gampong, nagari, kampung, negeri dan lain-lain) beserta hak-hak tradisionalnya.

Beberapa Undang-Undang yang secara ekslusif maupun mandiri, yang mengatur tentang desa sejak Indonesia merdeka. Undang-undang itu antara lain : Undang-Undang Nomor. 22 Tahun 1948 tentang Pokok Pemerintahan Daerah, Undang-Undang Nomor 1 tahun 1957 tentang Pokok-Pokok Pemerintahan Daerah, Undang-Undang Nomor 19 tahun 1965 tentang Desa Praja, Undang-Undang Nomor 5 Tahun 1974 tentang Pokok-Pokok Pemerintahan Di Daerah, Undang-Undang Nomor 5 Tahun 1979 tentang Pemerintahan Desa, Undang-Undang Nomor 22 Tahun 1999 tentang Pemerintahan Daerah, Undang-Undang Nomor 32 Tahun 2004 tentang Pemerintahan Daerah, ${ }^{4}$ Dalam pelak-sanaannya, pengaturan mengenai Desa ter-sebut belum dapat mewadahi segala kepen-tingan dan kebutuhan masyarakat Desa ${ }^{5}$. dan secara kuantitas pertumbuhan jumlah desa di Indonesia terus mengalami peningkatan yang hingga saat ini sudah berjumlah se-kitar 74.053 (tujuh empat ribu lima puluh tiga ) Desa, dan kelurahan sekitar 8.300 (delapan ribu tiga ratus). Dalam sejarah pengaturan tentang desa, barulah secara mandiri diatur dalam Undang-undang Nomor 6 tahun 2014 Tentang Desa yang disusun dengan semangat mewujudkan amanat Undang-Undang Dasar 1945, Pasal 18B ayat (2) yang memberikan pengakuan terhadap kesatuan masyarakat hukum adat beserta hak tradisionalnya.

Pada pasal 6 ayat 1 dan 2 Undang-undang Nomor 6 tahun 2014 Tentang Desa disebutkan jenis desa terdiri atas desa dan desa adat, yang penyebutannya disesuaikan dengan yang berlaku didaerah setempat. Salah satu penjelasan Undang-Undang tersebut dinyatakan bahwa tujuan UU No.6 Tahun 2014 ialah memberikan pengakuan dan penghormatan atas Desa yang sudah ada dengan keberagamannya sebelum dan sesudah terbentuknya Negara Kesatuan

1. Silahuddin, 2015. Buku I Kewenangan Desa dan Regulasi. Kementerian Desa, Pembangunan Daerah Tertinggal, Dan transmigrasi republik Indonesia, Jakarta. hal.11

2. Penjelasan pasal 18 Undang-Undang Dasar Negara Republik Indonesia dalam The Liang Gie, 1993. Pertumbuhan Pemerintah

Daerah di Negara Republik Indonesia, Jilid I Edisi Kedua. Gunung Agung. Jakarta, hal.35

3. Undang-Undang Dasar 1945 pasal 18 ayat b ayat 2

Silahuddin, 2015. Kewenangan Desa dan Regulasi Desa. Kementerian Desa, Pembangunan Daerah Tertinggal, Dan Transmigrasi Republik Indonesia, Jakarta. hal.11

5. Zudan Arif Fakrulloh, Kedudukan Dan Penetapan Desa Dan Desa Adat Berdasarkan Undang-Undang Nomor 6 Tahun 2014. Jurnal Hukum 'Inkracht', Volume I, Nomor 1, Nopember 2014 Program Pascasarjana Universitas Borobudur 
Republik Indonesia ${ }^{6}$.

Berdasarkan regulasi baru tentang desa tersebut, Kabupaten Siak Provinsi Riau satusatunya Kabupaten yang dengan cepat mengimplementasikannya, dengan mengeluarkan Peraturan Daerah Nomor 1 tahun 2015 tentang perubahan nama Desa menjadi Kampung, perubahan tersebut bertujuan untuk melestarikan kembali nama kampung dimasa lalu dalam bahasa Melayu yang pernah digunakan sebelum terbentuknya Kabupaten Siak. ${ }^{7}$ Selanjutnya, Pemerintah Kabupaten Siak juga menetapkan Peraturan Daerah Nomor 2 tahun 2015 tentang penetapan Kampung Adat di Kabupaten Siak. Adapun kampun adat yang ditetapkan ialah Kampung Adat Lubuk Jering, Kampung Adat Kampung Tengah, Kampung Adat Kuala Gasib, Kampung Adat Asli Anak Rawa Penyengat, Kampung Adat Sakai Minas, Kampung Adat Sakai Mandi Angin, Kampung Adat Sakai Bekalar dan Kampung Adat Sakai Libo Jaya. Tujuan ditetapkannya Kampung Adat adalah untuk menghidupkan kembali peranan tokoh adat dalam penyelenggaraan pemerintahan, pembangunan dan pelayanan kepada masyarakat, hal ini diakibatkan oleh semakin kompleknya tata kehidupan dimasyarakat sebagai pengaruh urbanisasi penduduk dari daerah lain, dan memberikan peran dan fungsi kepada Penghulu Kampung Adat dan tokoh adat untuk dapat mengayomi kehidupan masyarakat yang lebih optimal. ${ }^{8}$

Eksistensi Pemerintahan Kampung Adat di Siak sudah hampir hilang, yang diakibatkan pada masa pemerintahan orde baru berkuasa, pemerintah pusat melakukan penyeragaman kesatuan masyarakat hukum sesuai dengan adat istiadat yang diakui masyarakat menjadi pemerintahan desa melalui pemberlakuan Undang-Undang Nomor 5 Tahun 1979 tentang Pemerintahan Desa. Akibatnya adat budaya asli masyarakat Kampung dalam menyelenggarakan pemerintahan kampung adat hampir hilang sejak era pemerintahan orde baru.

Dari hasil penelitian terdahulu, ada beberapa permasalahan yang muncul terkait dengan pelaksanaa pemerintahan Kampung Adat di Kabupaten Siak dalam penyelenggaraan pemerintahan, pembangunan dan pelayanan kepada masyarakat: Pertama, pelestarian adat istiadat belum bisa dilakukan secara maksimal, karena tokoh-tokoh adat yang ada dikampung tidak ada lagi yang mengetahui sejarah secara detail. Kedua, banyaknya masyarakat pendatang dari daerah lain membuat norma, nilai-nilai adat Istiadat, tradisi, budaya dan hukum adat Kampung menjadi hampir hilang atau punah. Ketiga, Lembaga Adat Kampung atau Majelis Kerapatan Adat belum melakukan penggalian adat istiadat dan budaya secara maksimal ${ }^{9}$. Keempat, dalam pelaksanaan hukum adat masih terkendala terkait kesepakatan penerapan hukum adat sesuai adat istiadat dengan penegakan hukum nasional yang dilaksanakan oleh aparat penegak hukum (polisi). Kelima, pemerintah kampung adat masih terkendala dalam penerapan hukum adat, apakah juga berlaku bagi masyarakat pendatang atau tidak. Keempat, masih adanya kekosongan regulasi di Tingkat Provinsi yang mengatur tentang Desa Adat sehingga Pemerintah Daerah di Kabupaten Siak belum bisa membuat regulasi lanjutan berupa Peraturan Bupati yang mengatur tentang pelaksanaan Kampung Adat. Sehingga dalam penyelenggaraan pemerintahan kampung adat menimbulkan ketidak jelasan susunan kelembagaan, pengisian jabatan, dan masa jabatan Penghulu Kampung Adat ${ }^{10}$.

\footnotetext{
${ }^{6}$. Undang-Undang Negara Republik Indonesia Nomor 6 Tahun 2014 Tentang Desa. di Undang di Jakarta Pada Tanggal 15 Januari 2014. Lembaran Negara Republik Indonesia Tahun 2014 Nomor 7

7. Peraturan Daerah Kabupaten Siak nomor 1 tahun 2015 tentang perubahan nama desa menjadi Kampung, diundangkan di Siak Sri Indrapura Pada Tanggal 9 Maret 2015. Lembaran Daerah Kabupaten Siak No 5, Noreg Peraturan Daerah Kabupaten Siak Provinsi Riau : 7.08.C/2015

${ }^{8}$. Peraturan Daerah Kabupaten Siak nomor 2 tahun 2015 tentang penetapan Kampung Adat di Kabupaten Siak. diundangkan di Siak Sri Indrapura Pada Tanggal 15 Januari 2015 Lembaran Daerah Kabupaten Siak No 2, Noreg Peraturan Daerah Kabupaten Siak : 7.04.c/2015.

9 . Agustina Panca. Upaya Pemerintah Kampung Adat Kuala Gasib Kecamatan Koto Gasib Kabupaten Siak dalam Melestarikan Adat Istiadat. JOM FISIP Universitas Riau Vol. 4 No. 12017

10. Mukhtar. Eksistensi Kelembagaan Kampung Adat Tengah Kecamatan Mempura Kabupaten Siak. JOM FISIP Universitas Riau Vol. 4 No. 12017
} 
Masalah lainnya mengenai peran adat dalam penyelenggaraan pemerintahan desa, dari hasil penelitian (Adhiharinalti), menyebutkan dalam konteks implementatif di daerah-didaerah ada hubungan yang khas antara penerapan adat dan penyelenggaraan pemerintahan desa. Di Papua, lembaga adat sangat dominan sedangkan desa dinas tidak mempunyai pengaruh. Berbeda dengan di Jawa, sebagian besar Sulawesi, Kalimantan Timur, dan sebagian Sumatera, didaerah tersebut, pengaruh adat sangat kecil. Desa dinas sudah tumbuh kuat. Di Sumatera Barat, terjadi kompromi antara adat dan desa dinas, karena lembaga adat dan desa dinas sama-sama kuat. Di Bali, seperti juga di Kalimantan Barat, Aceh, Nusa Tenggara Timur dan Maluku, pengaruh adat jauh lebih kuat ketimbang desa dinas ${ }^{11}$.

\section{Perumusan Masalah}

Berdasarkan latar belakang tersebut diatas, maka rumusan masalah yang akan diteliti adalah a). Bagaimana Proses Kebijakan Penetapan Pemerintahan Kampung Adat di Kabupaten Siak ?. b). Bagaimana Pelaksanaan Penyelenggaraan Pemerintahan Kampung Adat di Kabupaten Siak? c). Apa saja faktor penghambat dalam Pelaksanaan Penyelenggaraan Pemerintahan Kampung Adat di Kabupaten Siak?.

Secara teori Desa Adat Menurut Widya Setya Dharma Desa Adat merupakan kesatuan masyarakat dimana rasa kesatuan sebagai warga desa adat terikat oleh wilayah tertertentu (karang desa) dengan batas-batas yang jelas dan terikat ${ }^{12}$. Sedangkan menurut Sarasehan Desa Adat juga merupakan kesatuan masyarakat hukum adat, yang mana memiliki wewenang mengatur daerah atau wilayahnya sendiri dengan lebih menegakkan hukum adat dalam masyarakat. Masyarakat desa adat juga disebut sebagai masyarakat adat, masyarakat adat merupakan suatu kesatuan masyarakat yang bersifat otonom, mendiami sebuah kawasan teritorial dimana mereka mengatur sistem kehidupannya, berkembang dan dijaga oleh masyarakat itu sendiri. ${ }^{13}$ Sejalan dengan pendapat Sutoro Eko Desa Adat adalah sebuah kesatuan masyarakat hukum adat yang secara historis mempunyai batas wilayah dan identitas budaya yang terbentuk atas dasar teritorial yang berwenang mengatur dan mengurus kepentingan masyarakat Desa berdasarkan hak asal usul. ${ }^{14}$

Berdasarkan Peraturan Daerah Kabupaten Siak Nomor 2 Tahun 2015 pada pasal 1 ayat 10 disebutkan Kampung Adat (Desa Adat) adalah susunan asli yang mempunyai hak asal usul berupa hak mengurus wilayah dan mengurus kehidupan masyarakat hukum adatnya. Selanjutnya, pada pasal 1 ayat 11 juga disebutkan yang dimaksud dengan adat ialah ketentuan dan aturan yang mengatur tingkah laku anggota masyarakat dalam hubungan sesamanya dalam segala aspek kehidupan.

Beratha menyebut, Otonomi desa merupakan otonomi yang khas/asli bangsa Indonesia, yang sudah tumbuh dan berkembang dalam kehidupan masyarakat Indonesia seiring dengan perkembangan peradabannya, serta diperoleh secara tradisional atau bersumber dari hukum adat (asli Indonesia), perwujudannya tercermin dalam tata kehidupan masyarakat atau pemerintahan desa adat"

Hampir senada dengan Zakaria, dkk. Menyebut, bila dilihat dengan menggunakan pendekatan teori politik - hukum, otonomi desa identik dengan, atau dapat digolongkan

\footnotetext{
11. Adhiharinalti. Eksistensi Hukum Adat Dalam Penyelenggaraan Pemerintahan Desa di Bali. Jurnal RechtsVinding, Media Pembinaan Hukum Nasional, Vol. 1 No. 3, Desember 2012, hlm. 410

12. Agustina Panca, op.cit. hal 4

13. ibid. hal 4

${ }^{14}$. Eko Sutoro, 2015. Regulasi Baru, Desa Baru, Ide, Misi, dan Semangat UU Desa. Kementerian Desa, Pembangunan Daerah Tertinggal, Dan transmigrasi republik Indonesia, Jakarta. hal. 44
} 
kedalam hak yang bersifat bawaan, yakni hak yang telah tumbuh, berkembang dan terpelihara dalam suatu kelembagaan (institution) yang merupakan urusan rumah tangga sendiri ${ }^{15}$.

Soetardjo Kartohadikoesoemo,1962. Ndraha, 1991. HAW Widjaja,2003. mengatakan; Otonomi desa merupakan otonomi asli, bulat, dan utuh serta bukan merupakan pemberian dari pemerintah. Sebaliknya pemerintah berkewajiban menghormati otonomi asli yang dimiliki oleh desa. Sebagai kesatuan masyarakat hukum yang mempunyai susunan asli berdasarkan hak istimewa, desa dapat melakukan perbuatan hukum baik hukum publik maupun hukum perdata, memiliki kekayaan, harta benda serta dapat dituntut dan menuntut di muka pengadilan. Susunan asli dan hak asal-asal atau sering disebut hak bawaan atau hak purba merupakan jantung konsep otonomi asli desa ${ }^{16}$.

Pendapat para ilmuan sosial diatas, mengenai konsep otonomi desa terjewantahkan, melalui UU No. 6 tahun 2014 Tentang Desa yang isinya mengangkat kembali otonomi desa berbasis jati diri desa, mengakomodasi keanekaragaman \& keunikan budaya tiap desa berdasarkan asal-usul dan adat istiadat, didalam sebuah negara kesatuan Republik Indonesia. Maka didalam UU ini dikenal desa adat atau nama lain, dan lembaga adat.. ${ }^{17}$

\section{Metode Penelitian}

Penelitian ini dilaksanakan di Kampung Adat Kampung Tengah, Kuala Gasib, Lubuk Jering, Sakai Bekalar Kabupaten Siak. Jenis penelitian dalam penelitian ini adalah deskriptif kualitatif.. sumber data primer diperoleh melalui observasi (pengamatan) yang dimulai pada tahap deskripsi yaitu peneliti memasuki situasi sosial (tempat, aktor, aktivitas), kemudian tahap reduksi menentukan fokus memilih diantara yang telah dideskripsikan. Kemudian tahap seleksi yaitu peneliti mengurai fokus menjadi komponen yang lebih rinci ${ }^{18}$ Data primer juga diperoleh melalui Wawancara mendalam (indepht interview) dengan para narasumber/informan. Dengan menggunakan teknik purposive sampling dan snowball sampling dalam memilih dan menentukan informan/ subjek penelitian. Data skunder Peraturan Daerah Kabupaten Siak, dan Peraturan Perundang-Undangan yang berhubungan dengan desa, Profil Kampung Adat. Selain dari data primer dan data sekunder, sumber data juga diperoleh dari literature kepustakaan yang berhubungan dengan masalah penelitian.

Data yang terkumpul dianalisis dengan pendekatan analisis data kualitatif model Miles Huberman Interactive Model Of Analysis (Biglen \& Bogdan, 1998) ${ }^{19}$ secara sederhana dapat digambarkan:

\footnotetext{
15 . Dikutip dari berbagai sumber. Beratha, 1991 Zakaria dkk, 2001, dalam Tesis Firmanudin Agus. 2005. "Kajian Tentang Implementasi Kebijakan Otonomi Desa Berdasarkan Undang Undang Nomor 22 Tahun 1999 Ditinjau Dari Aspek Kelembagaan Dan Pembiayaan Pemerintahan Desa Di Kecamatan Cipari Kabupaten Cilacap”. Pascasarjana Program Studi Ilmu Administrasi Publik Universitas Jenderal Soedirman Purwokerto, hal. 25

16 . Eko Sutoro op.cit. hal 94

${ }^{17}$.Penjelasan Undang-Undang Negara Republik Indonesia Nomor. 6 Tahun 2014 Tentang Desa)

${ }^{18}$. Sugiyono, 2012. Metode Penelitian Kuantitatif, Kualitatif dan RD. Bandung, Alfabeta. Hal. 228-230

${ }^{19}$. Biglen \& Bogdan, 1998. Qualitative research Methodology. New York: Harper and Row
} 


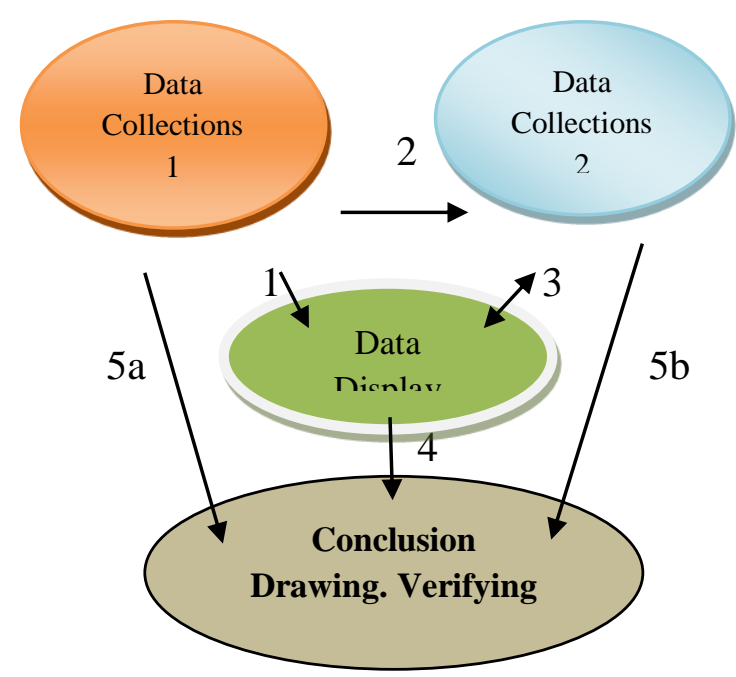

Wiliam Wiersma,1986, mengatakan untuk menguji validitas dan reliabilitas data, digunakan pengujian dengan cara Triangulasi sumber data dan teknik pengumpulan data. ${ }^{20}$ Dengan demikian terdapat triangulasi teknik pengumpulan data dan triangulasi teknik pengumpulan data (observasi, wawancara dan dokumentasi/kepustakaan).

\section{Hasil Dan Pembahasan}

\section{Kedudukan Pemerintahan Kampung Dalam Sistem Pemerintahan Kerajaan Siak}

Secara ringkas sistem pemerintahan Kerajaan Siak dipimpin oleh Sultan (Raja) yang dibantu oleh satu Dewan yang disebut "Dewan Kesultanan". Dewan Kesultanan itu terdiri dari tiga kelompok, yaitu: ${ }^{21}$

1. Datuk Empat Suku yang merupakan penasehat utama Sultan, mereka adalah:
a. Datuk Lima Puluh;
b. Datuk tanah Datar;
c. Datuk Pesisir; dan
d. Datuk Kampar.

2. Tunggal Manah, yaitu kelompok penasehat Sultan dalam adat, mereka adalah :
a. Penghulu-penghulu yang tertua;
b. Batin-batin yang tertua; dan
c. Para ketua.

3. Orang besar kerajaan, yaitu pembantu sultan dalam urusan pertahanan, mereka terdiri dari:
a. Panglima perang;
b. Datuk hamba raja;
c. Datuk bintara kiri;
d. Datuk bintara kanan; dan
e. Datuk bendahara (pemegang perbendaharaan istana).

\footnotetext{
20. Sugiyono op.cit, hal 273

${ }^{21}$. O.K, Nizami Jamil dkk, Sejarah Kerajaan Siak,2014. dikutip dalam bukunya Dodi Haryono (et al), dengan judul model penataan kelembagaan pemerintahan kampung adat di Kabupaten Siak., 2016. Alaf riau; Pekanbaru. Hal. 67
} 
Di luar pusat pemerintahan, Kesultanan Siak Sri Indrapura juga mengatur sistem pemerintahan di daerah. Pemerintahan di daerah-daerah dipegang oleh Kepala Suku yang bergelar Penghulu, Orang Kaya, dan Batin. Ketiga jabatan tersebut sama kedudukannya, hanya saja Penghulu tidak mempunyai hutan tanah. Dalam menjalankan tugasnya Penghulu dibantu oleh:22

a. Sangko Penghulu (wakil Penghulu);

b. Malim Penghulu (pembantu urusan kepercayaan/agama); dan

c. Lelo Penghulu (pembantu urusan adat sekaligus berfungsi sebagai Hulubalang).

Batin dan Orang Kaya adalah orang yang mengepalai suku asli. Jabatan ini didapat secara turun temurun. Batin mempunyai hutan tanah (ulayat). Dalam menjalankan tugasnya, Batin dibantu oleh:

a. Tongkat (pembantu Batin dalam urusan yang menyangkut kewajiban-kewajiban terhadap sultan);

b. Monti (pembantu Batin urusan adat); dan

c. Antan-antan (pembantu Batin yang sewaktu-waktu dapat mewakili Tongkat atau Monti jika keduanya berhalangan).

Sistem Pemerintahan Kampung di Siak secara hukum tercantum pada Peraturan Pemerintahan Kerajaan Siak tahun (1915). Pada Pasal 1 disebutkan bahwa Pemerintahan Kerajaan Siak dibagi 5 (lima) distrik yaitu Siak, Pekanbaru, Bagan Api-Api, Bukit Batu, dan Selat Panjang. Setiap distrik diperintah oleh seorang kepala distrik dan setiap distrik dibagi dengan beberapa onderdistrict, dan beberapa onderdistrict dibagi dengan beberapa kampungkampung yang dikepalai oleh Datuk atau Penghulu. ${ }^{23}$ Berdasarkan peraturan ini, dapat disimpulkan bahwa satuan pemerintahan terbawah dalam sistem Pemerintahan Kerajaan Siak yang terakhir Sultan Syarif Qaim II sejak Tahun 1915-1945 adalah sistem Pemerintahan Kampung yang dikepalai oleh Penghulu atau Batin.

\section{Kebijakan Proses Penetapan Pemerintahan Desa Menjadi Pemerintahan Kampung Adat di Kabupaten Siak}

Penetapan Desa Adat atau dengan nama lain dalam ketentuan UU No. 6 tahun 2014, pada pasal 98 ditetapkan oleh melalui pemerintah daerah kabupaten/kota. selanjutnya, pada pasal 100 disebutkan "desa dan kelurahan" dapat dilakukan perubahan status. Perubahan status sebagaimana disebutkan dalam Peraturan Pemerintah (PP) No. 43 tahun 2014 sebagaimana telah diubah dengan PP No. 47 tahun 2015, pasal 20 meliputi : Desa menjadi kelurahan. kelurahan menjadi Desa. Desa adat menjadi Desa, dan Desa menjadi Desa adat. Pada pasal 28 disebutkan Pemerintah, pemerintah daerah provinsi, dan pemerintah daerah kabupaten/kota dapat mengubah status Desa menjadi Desa adat ${ }^{24}$.

Dari peluang yang diberikan oleh peraturan perundang-undangan tersebut, maka pemerintah Kabupaten Siak dalam upaya untuk mengembalikan nilai adat masyarakat lokal dan peranan tokoh masyarakat adat serta untuk menghidupkan kembali nilai dan norma adat di Kampung Adat, maka di dikeluarkan Peraturan Daerah Kabupaten Siak Nomor 2 Tahun 2015 tentang Penetapan Kampung Adat di Kabupaten Siak.

\footnotetext{
22. Yuli S. Setyowati, Sejarah Riau, Adicita Karya Nusa, Yogyakarta, 2004. dikutip dalam bukunya Dodi Haryono (et al), dengan judul Model Penataan Kelembagaan Pemerintahan Kampung Adat Di Kabupaten Siak., 2016. Alaf riau; Pekanbaru. Hal. 67

23. Wan Ghalib, 2002. Adat Istiadat Bidang Pemerintahan di Kerajaan Siak dan Pesukuan Melayu yang Ada di Kabupaten Siak, 2002. dikutip dalam bukunya Dodi Haryono (et al), dengan judul Model Penataan Kelembagaan Pemerintahan Kampung Adat Di Kabupaten Siak, 2016. Alaf riau; Pekanbaru. Hal. 72

${ }^{24}$. Dikutip dari Undang-Undang Nomor 6 tahun 2014 tentang desa, Peraturan Pemerintah No 43 tahun 2014 jo. Peraturan Pemerintah Nomor 47 tahun 2015 tentang pelaksanaan Undang-Undang Nomor 6 tahun 2014 tentang desa.
} 


\section{Proses Penetapan Pemerintahan Desa/Kampung Adat}

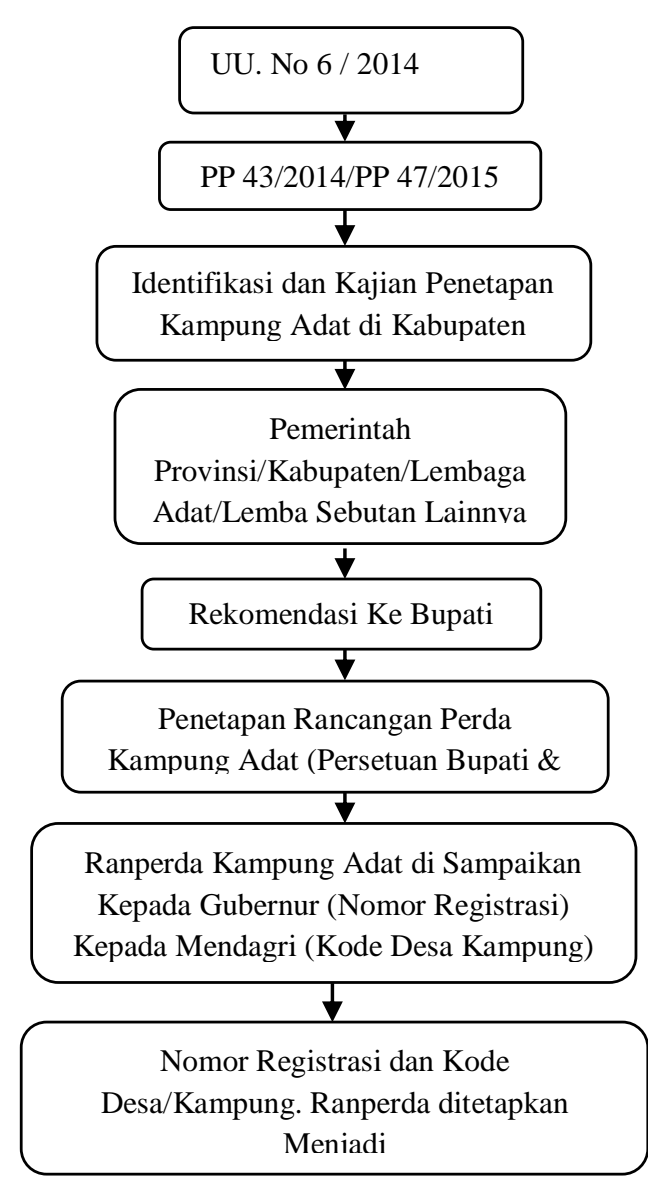

Sumber: Data Olahan Peneliti dikutip dari UU dan PP Tentang Desa.

Proses dan Mekanismen proses penetapan desa/kampung adat di Kabupaten Siak, dalam temuan peneliti dapat dijelaskan bahwa proses perubahan status belum berjalan secara ideal, hal tersebut terlihat bahwa Peraturan Pemerintah No 43 Tahun 2014 menyebutkan perubahan status desa menjadi desa adat dilakukan melalui mekanisme. Pertama, identifikasi dan pengkajian yang dilakukan oleh Pemerintah Provinsi Riau dan Pemerintah Kabupaten Siak bersama Majelis Adat atau lembaga lainnya. Kedua, Bupati Kabupaten Siak menetapkan Kampung Adat berdasarkan hasil identifikasi dan pengkajian yang dituangkan dalam Rancangan Peraturan Daerah (Ranperda) dan dibahas dan disetujui bersama dengan DPRD Kabupaten Siak. Ketiga, Rancangan Peraturan Daerah tersebut disampaikan kepada Gubernur untuk mendapatkan Nomor Registrasi Kampung Adat, dan kepada Menteri Dalam Negeri untuk mendapatkan Kode Kampung Adat. Selanjutnya, Ranperda tersebut ditetapkan menjadi Peraturan Daerah (Perda) setelah mendapat Nomor Registrasi dan Kode Kampung Adat dari Menteri Dalam Negeri.

Proses penetapan 8 (delapan) pemerintahan kampung adat di Kabupaten Siak melalui Perda No. 2 tahun 2015, dalam analisa peneliti, terkesan dilakukan melalui proses yang sangat cepat. Hal tersebut dapat dipahami karena, UU No. 6 tahun 2014 pasal 116 ayat 2 dan 3 menyebutkan bahwa :

"Pemerintah Daerah Kabupaten/Kota menetapkan Peraturan Daerah tentang penetapan Desa dan Desa Adat di wilayahnya, paling lama 1 (satu) tahun sejak Undang-Undang ini diundangkan". 
Namun, proses penetapan Desa Adat dalam ketentuan Peraturan Pemerintah No. 43 Tahun 2014 menyebutkan harus dilakukan melalui identifikasi dan pengakajian yang dilakukan secara bersama antara Pemerintah Provinsi dan Pemerintah Kabupaten, dan sebelum Peraturan Daerah tentang penetapan kampung adat ditetapkan oleh Kepala Daerah, idealnya harus mendapat nomor registrasi dari Gubernur Riau dan Kode desa/kampung adat dari Kementerian Dalam Negeri. Dari hasil data yang ditemukan peneliti, proses penetapan Kampung Adat di Kabupaten Siak belum sepenuhnya mengikuti prosedur dan mekananisme yang tepat, dan secara administrasi pemerintahan belum terpenuhi secara keseluruhan, karena sampai dengan ditetapkannya Peraturan Daerah Nomor 2 tahun 2015, sampai dengan saat ini, nomor registrasi Kampung Adat dari Gubernur Riau yang harus dituangakan dalam Peraturan Gubernur Riau dan Kode Desa/Kampung Adat dari Kementerian Dalam Negeri belum didapatkan.

Kebijakan penetapan Kampung Adat di Kabupaten Siak, dilakukan secara berjenjang. Pertama, Pemerintah Kabupaten Siak melakukan perubahan "nama" seluruh pemerintahan desa menjadi pemerintahan "Kampung", yang tertuang dalam Peraturan Daerah Kabupaten Siak Nomor 1 tahun 2015. Kemudian, dalam kurun waktu yang bersamaan Pemerintah Kabupaten Siak melakukan perubahan "status" 8 (delapan) Pemerintahan Kampung, menjadi berstatus "Pemerintahan Kampung Adat". (Perda No. 2 tahun 2015). Sementara, pengaturan turunan pengubahan status desa menjadi desa adat perubahan status desa dalam PP 43 tahun 2014, disebutkan diatur dengan Peraturan Menteri. Peraturan Menteri yang dimaksud, baru dikeluarkan pada tahun 2017, Peraturan Menteri Dalam Negeri RI Nomor 1 Tahun 2017 tentang Penataan Desa, yang ruang lingkupnya mengatur penataan desa dan desa adat. Penataan dimaksud ialah pembentukan Desa dan Desa Adat. penghapusan Desa dan Desa Adat; dan perubahan status Desa dan Desa Adat.

Dengan demikian, dalam pandangan peneliti, kebijakan perubahan nama pemerintahan desa menjadi pemerintahan "kampung" di Kabupaten Siak dari peraturan perundang-udangan sudah tepat. Namun, penetapan perubahan status pemerintahan desa/kampung menjadi pemerintahan kampung adat di Kabupaten Siak masih mengalami kerancuan ditinjau dari aspek prosedur dan mekanisme penetapan/perubahan status yang diatur dalam peraturan perundangundangan.

Kebijakan Pemerintah Kabupaten Siak dalam menetapkan perubahan nama pemerintahan desa menjadi "Kampung" dari Kampung menjadi pemerintahan "Kampung Adat" ditinjau dari aspek historinya, hasil keterangan Anggota DPRD Kabupaten Siak Bapak (Sujarwo) sebagai Pansus Ranperda menyebutkan :

Semangat untuk melakukan perubahan status desa menjadi kampung, dan menetapkan 8 (delapan) kampung adat di kabupaten siaka ialah untuk memunculkan kembali "batang terendam” kepermukaan. (Wawancara, 24 Agustus 2018)

Batang terendam dalam pandangan (Sujarwo) sebagai ketua pansus Ranperda yang dikemudian ditetapkan menjadi Perda Nomor 2 tahun 2015 maksudnya ialah mengangkat dan melestarikan kembali asal usul dan adat istiadat masyarakat melayu kabupaten siak sejak dahulu, dalam kehidupan sosial budaya, ekonomi, politik pemerintahan, keamanan dan ketertiban. Kebijakan Pemerintah Kabupaten Siak yang menetapkan 8 (delapan) Kampung Adat, karena dipandang 8 (delapan) Kampung tersebut memiliki historis masing-masing dan masing berpotensi untuk diangkat kembali dan dilestarikan.

Salah satu kampung yang ditetapkan menjang kampung adat ialah kampung tengah Kecamatan Mempura, Dari hasil keterangan wawancara dengan tokoh masyarakat Kampung Adat Kampung Tengah (Iskandar) menyebutkan

Penetapan kampung adat kampung tengah ialah karena sejarahnya dikampung tengah ada 4 (empat) datuk yaitu (1) Datuk Tanah Datar, (2) Datuk Pesisir, (3) Datuk 50, dan (4) 
Datuk Kampar. Keberadaan empat datuk ini menjadikan desa/kampung ini memiliki sejarah yang kuat dengan silsilah kerajaan di Kabupaten Siak. Masyarakat Desa Kampung Tengah masih menghormati dan memfungsikan keberadaan empat datuk ini dalam aktivitas masyarakat desa. (Wawancara, 23 Agustus 2018)

Dari hasil keterangan tersebut, Kampung adat Kampung Tengah memang merupakan salah satu Pusat Pemerintahan Kerajaan Siak yang didirikan oleh "Raja Kecil” yang bergelar Sultan Abdul Jalil Rakhmat Syah. Ketika pertama kali didirikan, pusat pemerintahan Kesultanan Siak Sri Indrapura berada di Buantan, kemudian berpindah ke Mempura, Senapelan Pekanbaru, kembali lagi ke Mempura. ${ }^{25}$. Kampung Tengah merupakan tempat tinggal bekas Petinggi Kerajaan Siak yang dahulu kala disebut Kampung Kelakap. Segala sesuatu yang terjadi di masyarakat didasarkan pada hukum adat Melayu dengan falsafah "adat bersendikan Syara', Syara' bersendikan Kitabullah ${ }^{26}$

Kampung Adat lainnya yang ditetapkan ialah Kampung Adat Lubuk Jering, dari historisnya, keterangan tokoh masyarakat/agama Bapak H. Muslim menyebutkan:

"Kampung lubukjering ini sudah ada sejak zaman sebelum kemerdekaan, suku aslinya ialah suku melayu, yaitu suku Suku Pandan, Suku Antan-Antan, Suku Geronggang, Suku Olak, Suku Botung, dan Suku Hamba Raja. Suku-suku tersebut mempunyai tanah adat/ulayat yang disebut tanah persukuan”. 14 . (Wawancara, 23 Agustus 2018)

Dari keterangan tersebut, suku-suku yang ada pada kampung adat lubuk jering, menunjukkan adanya masing-masing kepala suku sebagai datuk pemangku adat dalam penerapan hukum adat, dan kepala suku-suku tersebut dalam sistem pemerintahan kerajaan siak dipercaya oleh sultan sebagai pemimpin-pemimpin pemerintahan daerah kerajaajaan siak yang disebut sebagai penghulu, orang kaya, batin.

Peneliti melakukan wawancara Bapak (Hamzah) salah satu tokoh adat dan merupakan kepala dusun pada Kampung Adat Kuala Gasib. Dari hasil keterangannya menyebutkan:

Kampung Adat Kuala Gasib berada diantara Sungai Siak dan Sungai Gasib dan daerah ini dahulunya memiliki sejarah Kerajaan Siak dimana pernah berdiri sebuah Kerajaan yang bernama Kerajaan Gasib dan dalam sejarah menyebutkan bahwa Kerajaan Gasib adalah cikal bakal Kerajaan Siak Sri Indrapura. Kerajaan ini juga pernah mengalami masa jaya nya pada abad ke 14-15 Negeri ini terkenal dengan kegagahan panglima Gimbam dan Datuk Panglima Panjang dan konon kabarnya Raja Gasib mempunyai anak semata wayang yang sangat jelita yang bernama Putri Kaca Mayang, sebagai bukti sejarah di Kampung Kuala Gasib terdapat makam Putri Kaca Mayang yang saat ini berada diarea perkebunan perusahaan. (Wawancara, 24 Agustus 2018)

Dari hasil wawancara tersebut, penetapan Kampung Adat Kuala Gasib, sangat tepat dan beralasan karena Kuala Gasib mempunyai sejarah yang panjang dan pernah menjadi pusat kerajaan yang berjaya sebelum terbentuknya Pemerintahan Kerajaan Siak Sri Indrapura.

Kemudian, peneliti menelusuri sejarah penetapan Kampung Adat Sakai Bekalar, Kampung Adat Sakai bekalar yang sebelumnya disebut Desa Bekalar, pada tahun 2010 baru resmi menjadi desa definitif yang sebelumnya hanya sebuah dusun di Desa Belutu. Kampung Adat Sakai Bekalar pada saat ini berada pada area wilayah perkebunan kelapa sawit milik

\footnotetext{
25. Norma Dewi et.al, Selintas Sejarah Kerajaan Siak Sri Indrapura dan Peninggalannya, 2000. dikutip dalam bukunya Dodi Haryono (et al), dengan judul Model Penataan Kelembagaan Pemerintahan Kampung Adat Di Kabupaten Siak, 2016. Alaf riau; Pekanbaru. Hal. 66

26. Dokumen Notulen Rapat Sosialisasi Desa Adat, Pemerintah Desa Kampung Tengah, 2014.
} 
perusahaan Ivomas Tunggal (Grup Sinar Mas) yang telah memulai operasinya di Kecamatan Kandis sejak Tahun $1987^{27}$.

Dari hasil keterangan tokoh masyarakat Bapak (Husai) menyebutkan

ditetapkannya Kampung Adat Sakai Bekalar karena masyarakat Suku Sakai adalah penduduk asli tempatan yang secara turun temurun merupakan penghuni kampung Adat ini sejak sebelum Indonesia merdeka yang mempunyai hutan tanah dengan adat istiadat dibawah naungan Batin Limo Bomban Mineh yang diangkat, dan diserahkan oleh Kerajaan Siak untuk mengatur dan mengurus kepentingan masyarakatnya". (Wawancara, 24 Agustus 2018)

Masyarakat Suku Sakai adalah penduduk asli tempat di kampung ini sejak sebelum Indonesia merdeka, memiliki hutan tanah adat yang diakui dan dihormati hak tradisional oleh Pemerintah Kerajaan Siak dibawah kepemimpinan Batin Belutu yang diberikan kewenangan sepenuhnya untuk mengatur dan mengurus kepentingan masyarakatnya. ${ }^{28}$

\section{Pelaksanaan Penyelengaraan Pemerintahan Kampung Adat Di Kabupaten Siak}

Penyelenggaraan pemerintahan kampung adat yang telah ditetapkan, haruslah diselenggarakan sesuai dengan asal usul dan adat istiadat yang masih hidup di Kampung Adat. UU No.6/2014 pasal 107 menyebutkan;

"Pengaturan dan penyelenggaraan Pemerintahan Desa Adat dilaksanakan sesuai dengan hak asal usul dan hukum adat yang berlaku di Desa Adat yang masih hidup serta sesuai dengan perkembangan masyarakat dan tidak bertentangan dengan asas penyelenggaraan Pemerintahan Desa Adat dalam prinsip Negara Kesatuan Republik Indonesia." Selanjutnya pasal 108 menyebutkan;

"Pemerintahan Desa Adat menyelenggarakan fungsi permusyawaratan dan Musyawarah Desa Adat sesuai dengan susunan asli Desa Adat atau dibentuk baru sesuai dengan prakarsa masyarakat Desa Adat."

Pengaturan dan penyelenggaraan Pemerintahan Desa (Kampung) Adat dilaksanakan sesuai dengan hak asal usul dan hukum adat yang berlaku di Desa (Kampung) Adat, dalam setiap produk hukum yang dikeluarkan, Undang-Undang No.6 tahun 2014 pasal 110 menyebutkan: Peraturan Desa Adat disesuaikan dengan hukum adat dan norma adat istiadat yang berlaku di Desa Adat sepanjang tidak bertentangan dengan ketentuan peraturan perundang-undangan.

Peraturan Desa/Kampung adat berdasarkan asal usul ruang lingkupnya, juga diatur secara jelas didalam Peraturan Menteri Desa Tertinggal dan Transmigrasi Nomor 1 Tahun. 2015 tentang Pedoman Kewenangan Berdasarkan Hak Asal Usul dan Kewenangan Lokal Berskala Desa. Kewenangan berdasarkan Hak Asal Usul meliputi:

1. Penataan sistem organisasi dan kelembagaan masyarakat adat

2. Pranata hukum adat

3. Pemilikan hak tradisional

4. Pengelolaan tanah ulayat

5. pengelolaan tanah kas desa adat

6. kesepakatan dalam kehidupan masyarakat desa adat

7. pengisian jabatan kepala Desa adat dan perangkat Desa adat

\footnotetext{
${ }^{27}$ Profil Kampung Sakai Bekalar, 2017.

28 . Dokumen Permohonan Desa Adat, Pemerintah Desa Bekalar . 2014.
} 
8. masa jabatan kepala Desa adat ${ }^{29}$

Dari hasil temuan penelitian, pada 4 (empat) kampung adat di Kabupaten Siak, pelaksanaan hak asal usul dan adat istiadat dalam pengaturan dan penyelenggaraan pemerintahan kampung adat belum dilakukan pada pemerintahan Kampung Adat Kampung Tengah, Kuala Gasib, Lubuk Jering dan Kampung Adat Sakai Bekalar. Penataan sistem organisasi pemerintahan barulah sekedar melakukan perubahan nama Susunan Organisasi Tata Kerja (SOTK) pemerintahan. Perubahan tersebut terkait dengan penyebutan nama jabatan.

Tabel. Perubahan Nama Jabatan Pemerintahan Desa Menjadi Kampung

\begin{tabular}{|r|l|c|}
\hline No & \multicolumn{1}{|c|}{ Desa } & Kampung \\
\hline 1 & Kepala Desa & Penghulu \\
\hline 2 & Sekretaris Desa & Kerani \\
\hline 3 & Kepala Urusan & Juru Tulis \\
\hline 4 & Kepala Dusun & Kepala Dusun \\
\hline 5 & Rukun Warga & Rukun Kampung \\
\hline 6 & Rukun Tetangga & Rukun Tetangga \\
\hline
\end{tabular}

Berdasarkan Peraturan Daerah Kabupaten Siak Nomor 2 tahun 2015 tentang Penetapan Kampung Adat di Kabupaten Siak pada pasal 4 disebutkan pemerintah kampung adat terdiri dari Penghulu; dan Perangkat Kampung Adat. Perangkat Kampung Adat terdiri dari Sekretariat Kampung Adat, Unsur kewilayahan, dan Pelaksana teknis lapangan.

Sekretariat Kepenghuluan Adat terdiri dari Kerani sebagai pimpinan sekretariat; dan Juru tulis, staf, atau unsur pembantu kerani. Unsur kewilayahan adalah Pembantu Penghulu yakni kadus, rukun kampung dan rukun tetangga. Sedangkan, Pelaksana teknis lapangan yaitu petugas Kampung Adat yang melakukan suatu tugas tertentu dalam perkampungan Adat seperti urusan agama, keamanan, pengairan, pertanian, pemadaman kebakaran hutan dan lahan atau urusan lain yang jumlahnya disesuaikan dengan kebutuhan dan kondisi sosial budaya masyarakat setempat.

Dari susunan organisasi pemerintahan kampung adat yang dipraktekkan pada saat ini, sebagaimana yang diatur dalam Perda No.2/2015 telah dilakukan penyesuaian mengikuti perkembangan susunan organisasi Pemerintahan desa sebagaimana yang diatur didalam Peraturan Menteri Dalam Negeri Nomor 84 Tahun 2015 Tentang Susunan Organisasi dan Tata Kerja Pemerintahan Desa. artinya, susunan organisasi pemerintahan kampung adat hanyalah melakukan perubahan nama jabatan.

Adapun Fungsi dan kewenangan Pemerintah Kampung Adat berdasarkan Peraturan Daerah No 2 Tahun 2015 pasal 6 ayat 1 dan 2 disebutkan:

Kampung adat memiliki fungsi Pemerintahan, Keuangan, Pembangunan, serta mendapat fasilitasi dan pembinaan dari Pemerintah Kabupaten. Kampung adat pada dasarnya melakukan tugas yang hampir sama dengan Desa/Kampung, sedangkan perbedaannya hanyalah dalam pelaksanaan hak asal usul, terutama menyangkut kelestarian sosial, pengaturan dan pengurusan wilayah adat, sidang perdamaian adat, pemeliharaan ketentraman dan ketertiban bagi masyarakat hukum adat, serta pengaturan pelaksanaan pemerintahan berdasarkan susunan asli.

\footnotetext{
29. Peraturan Menteri Desa Tertinggal dan Transmigrasi Nomor 1 Tahun. 2015 tentang Pedoman Kewenangan Berdasarkan Hak Asal Usul dan Kewenangan Lokal Berskala Desa. di Undangkan
} 
Untuk mencapai penyelenggaraan Pemerintahan, Pembangunan, dan pelayanan kepada masyarakat serta tidak melanggar adat-istiadat, Kampung Adat mempunyai kewenangan:

a. Pengaturan dan pelaksanaan Pemerintahan berdasarkan susunan asli.

b. Pengaturan dan pengurusan ulayat atau wilayah adat.

c. Pelestarian nilai sosial budaya kampung adat

d. Penyelesaian sengketa adat berdasarkan hukum adat yang berlaku dikampung adat dalam wilayah yang selaras dengan prinsip hak asasi manusia dengan mengutamakan penyelesaian secara musyawarah.

e. Penyelenggaraan sidang perdamaian peradilan kampung adat sesuai dengan ketentuan peraturan perundang-undangan

f. Pemeliharaan ketentraman dan ketertiban masyarakat desa adat berdasarkan hukum adat yang berlaku di kampung adat; dan

g. Pengembangan kehidupan hukum adat sesuai dengan kondisi sosial budaya masyarakat kampung adat.

Untuk melaksanakan tugas, fungsi dan kewenangan Pemerintah Kampung Adat, dalam Perda No.2/2015 juga mengatur mengenai Lembaga Kemasyarakatan Adat dan Lembaga Adat, yang dibentuk di masing-masing adat dengan Peraturan Kampung Adat sebagai wadah mitra pemerintah kampung adat. Salah tugas Lembaga Adat yang diatur Perda tersebut ialah memilih penghulu kampung sesuai dengan peraturan yang berlaku. Hal ini bermakna bahwa pengisian jabatan kepala penghulu kampung tidak menggunakan sistem pemilihan langsung oleh masyarakat sebagaimana sistem pengsian jabatan kepala desa pada umumnya, artinya pengsisian jabatan pemerintah kepala penghulu kampung adat dilakukan melalui mekanisme musyawarah mufakat melalui sidang majelis kerapatan adat.

Didalam penjelasan Undang-Undang No.6/2014 disebutkan: Jabatan Kepala Desa Adat diisi berdasarkan ketentuan yang berlaku bagi Desa Adat. Dalam hal terjadi kekosongan jabatan Kepala Desa Adat, Pemerintah Daerah Kabupaten/Kota dapat menetapkan penjabat yang berasal dari masyarakat Desa Adat yang bersangkutan.

Mengenai tata cara pengisian jabatan atau pengangkatan aparatur pemerintahan kampung adat ditinjau dari pendekatan historis, dalam administrasi pemerintahan Kesultanan Siak ialah Penghulu dipilih dan diangkat dari suatu suku tertentu secara turun temurun atau dari anak kemenakan keturunan Penghulu terdahulu dengan beberapa kriteria, antaranya:

a. Sepesukuan dengan Penghulu terdahulu.

b. Anak kemenakan dari keturunan Penghulu.

c. Berumur diatas 20 tahun.

d. Pandai dalam berunding dengan menggunakan norma adat.

Sedangkan pengangkatan para pembantu penghulu seperti Sangko Penghulu, Malim Penghulu serta Lelo Penghulu, Tongkat, Monti dan Antan-antan diserahkan kepada masingmasing Penghulu maupun Batin. ${ }^{30}$ Ditinjau dari nama-nama jabatan perangkat pemerintahan kampung adat yang termuat dalam Perda No.2/2015, penggunaan nama-nama tersebut belum sepenuhnya disesuaikan dengan susunan asli pemerintahan kampung yang pernah di peraktekkan pada masa pemerintahan kesultanan siak.

Dari hasil temuan peneliti pada Kampung Tengah, Kuala Gasib, Lubuk Jering, Sakai Bekalar, mengenai fungsi dan kewenangan sebagaimana yang disebutkan dalam perda No. 2

${ }^{30}$. Dodi Haryono, op.cit. Hal. 67 
/2015 belum terlaksana secara keseluruhan. Implikasi dari pemberlakukan Perda No.2/2015 menyebabkan terjadinya ketidakpastian dalam penyelenggaraan pemerintahan di 8 (delapan) kampung adat yang telah ditetapkan, sampai saat ini, pengisian jabatan kepala penghulu kampung adat belum dapat dilaksanakan, karena belum adanya regulasi yang mengatur tentang tata cara pengisian jabatan kepala penghulu dan perangkat kampung adat. Pasca pemberlakuan Perda No2/2015 jabatan penghulu kampung adat di jabat oleh Pejabat sementara (Pjs) dari Unsuar Aparatur Sipil Negara yang ditunjuk oleh Kepala Daerah Kabupaten Siak.

Dalam pelaksanaan penyelenggaraan pemerintahan Kampung adat dibutuhkan beberapa regulasi pendukung dalam dalam pelaksanaannya, UU No.6/2014 pasal 109 menyebutkan:

"Susunan kelembagaan, pengisian jabatan, dan masa jabatan kepala Desa Adat berdasarkan hukum adat ditetapkan dalam Peraturan Daerah Provinsi."

Belum adanya Peraturan Provinsi Riau yang mengatur sebagaimana yang dimaksud dalam pasal 109 UU No.6/2014 menyebabkan terjadinya ketidakpastian dalam melaksanakan pemerintahan Kampung Adat di Kabupaten Siak.

Kondisi tersebut diungkapkan oleh Bapak Sujarwo selaku Anggota DPRD Kabupaten Siak yang menjelaskan :

"Sekarang ini kami masih vakum untuk sementara waktu, tetapi kami selama ini hanya bisa menghimbau kepala penghulu dan tokoh masyarakat untuk memulai berbuat di kampung adat ini. Buatlah dulu dalam bentuk konsep apa saja yang diperlukan sekarang ini dalam kampung adat, hanya sebatas itu. Jadi maksud kami nanti dari konsep yang sudah dibuat tersebut, begitu nanti turun pergub kami bisa sesuaikan. Selain itu strategi ini juga kami gunakan untuk membendung penantian yang cukup lama ini akibat kode kampung adat yang belum didapatkan dan perda provinsi yang belum keluar" (Wawancara, 25 Agustus 2018)

Hal senada juga diungkapkan Dalam keterangan tokoh masyarakat mantas Kepala Desa/Kampung Tengah (Iskandar) mengatakan

Salah satu kendala utama dalam pelaksanaan asal usul dan adat istiadaat dalam penyelenggaraan pemerintahan Kampung Adat di Kampung Tengah ini adalah regulasi atau payung hukum dari pemerintah Propinsi Riau belum ada dalam bentuk Peraturan Daerah Propinsi Riau sebagaimana di syaratkan oleh Undang undang Desa Nomor 6 Tahun 2014 khususnya pasal-pasal yang berkaitan dengan pembentukan desa/kampung adat.selanjutnya Iskandar menyebut tidak jelas aturan pelaksanaannya, menjadikan masyarakat kampung terkotak- kotak. Keadaan seperti ini tidak kondusif dalam pelaksanaan pemerintahan kampung/desa. Selanjutnya Beliau mengtakan bahwa seandainya pembentukan desa kampung adat dapat terlaksana dengan baik, tidak akan menimbulkan gejolak dan perpecahan ditengah masyarakat. (wawancara, 23/8/2018)

Kemudian, peneliti menanyakan mengapa Perda tersebut belum dikeluarkan (Iskandar) menyebut:

"bahwa Gubernur Riau pada saat itu Bapak Andi Rahman belum terlalu merespon perubahan status desa menjadi kampung adat di Kabupaten Siak. Alasan inilah yang menyebabkan Peraturan Daerah Propinsi Riau tentang Kampung Adat belum pernah dibahas sampai saat ini antara DPRD (legislatif) dengan Gubernur Riau (eksekutif). (Wawancara, 23Agustus 2018)

Peranyataan (Iskandar) tersebut, bermakna bahwa proses politik kebijakan penetapan Kampung Adat di Kabupaten Siak tidak tersampaikan atau terkomunikasikan secara baik dengan pemerintah Provinsi Riau. 
Implementasi kebijakan penetapan Kampung adat di kabupaten Siak, belum bisa difungsikan sebagai paparan Plt. Kepala BPMPD Kabupaten Siak (Hazmizal) yang menyebutkan:

Pelaksanaannya terbentur, kode desa dari pemerintah pusat, yang hingga saat ini belum juga turun, ditambah lagi belum terbitnya Perda Provinsi Riau, sehingga kita kebingungan dalam menentukan tata kelola pemerintahan kampung adat, yang seharusnya kita tindak lanjuti dengan mengeluarkan Peraturan Bupati (Perbub), akibatnya kampung-kampung adat mengalami stagnasi bila ingin memilih kepala penghulu berdasarkan susunan asli mereka (kampung adat), karena belum mendapatkan pengakuan dari Kementerian Dalam Negeri, sementara jika kita mau melakukan seperti sistem pemerintahan desa administratif tidak mungkin lagi karena sudah ditetapkan menjadi kampung adat melalui perda kabupaten.

Untuk menyikapi kondisi kevakuman ini, Pemerintah Kabupaten Siak melalui BPMPD menyarankan kepada Pemerintahan Kampung Adat dan Tokoh Adat khususnya untuk segera menyusun suatu bentuk draf rancangan kelembagaan kampung atau peraturan adat sejenisnya sampai regulasi provinsi turun dan kode kampung adat didapatkan. Hal ini bertujuan agar setelah regulasi turun tinggal mengusulkan bentuk kelembagaan tersebut dan mengantisipasi kevakuman yang lebih lama lagi. Hal ini dapat dilihat dari wawancara bersama Bapak Abdul Razak Selaku Kaban BPMPD Kabupaten Siak berikut ini :

"Sekarang ini kami masih vakum untuk sementara waktu, tetapi kami selama ini hanya bisa menghimbau kepala desa dan tokoh masyarakat untuk memulai berbuat di desa adat ini. Buatlah dulu dalam bentuk konsep apa saja yang diperlukan.jadi nanti tinggal laksanakan ketika perda provinsi suda keluar dank ode kampung didapatkan dari Menteri" (Selasa, 26 Juli 2016)

Selanjutnya, peneliti mengkonfirmasi mengenai kesiapan-kesiapan Kampung Adat dalam melaksanakan Perda No2/2015. Kepada Bapak (Iskandar) yang menyebutkan

Samapai saat ini, Lembaga Adat Melayu (LAM) Kabupaten Siak, Lembaga Adat Melayu (LAM) Kecamatan Mempura di Kabuapaten Siak, tidak ada persiapan dan usaha-usaha untuk pelaksanaan Perda No.02 Tahun 2015 Tentang Pembentukan Kampung Adat di Kabupaten Siak. (Wawancara, 23 Agustus 2018)

Kemudian, keterangan dari Bapak Basri Hasan Pjs. Penghulu Kampung Kuala Gasib menyebutkan:

Salah satu langkah atau upaya yang dilakukan oleh Kampung Adat Kuala Gasib sejak ditetapkan menjadi Kampung Adat ialah upaya Lembaga Adat Melayu Kecamatan Koto Gasib yang mengeluarkan keputusan Lembaga Adat Melayu Riau Kecamatan Koto Gasib Nomor 1 Tahun 2015 yang menetapkan susunan pengurus Lembaga Adat Melayu Riau Kampung Kuala Gasib 2015-2020 yang terdiri dari Majelis Kerapatan Adat (MKA) dan Pengurus Harian yang terdiri dari 6 (enam) bidang, dalam rangka untuk melakukan upaya menggali asal-usul dan adat istiadat (kearifan lokal) yang ada di Kampung Adat Kuala Gasib. Namun masih terkendala dari sisi anggaran untuk melakukan penggalian tersebut, kemudian belum ada sarana pendukung, dan sulitnya untuk menggali asal usul hukum adat, karena tokoh-tokoh adat yang mengetahui sudah banyak yang tidak dan teks-teks adat juga sulit untuk ditemukan.

Kesiapan pelaksanaan Kampung Adat di Lubuk Jering, Peneliti melakukan Wawancara dengan Pjs. Kampung Adat Lubuk Jering Bapak (Irwansyah), menyebutkan : 
Kampung ini sudah melakukan inventarisir tokoh-tokoh adat, tanah ulayat lebih kurang 500 ha. Bapak Irwansyah juga mengatakan bahwa mekanisme pengambilan kebijakan di pemerintahan kampung sudah banyak dengan menggunakan azas musyawarah. Persiapan untuk aktivitas pemerintahan yang bercirikan kampung adat, telah banyak dilakukan oleh pemerintahan desa Lubuk Jering

Berikutnya, pernyataan Tokoh Adat/Agama Lubuk Jering Bapak H. Muslim menyebut

LAM Kampung Lubuk Jering telah berusaha untuk memulai menyusun draff aturan adat yang akan diberlakukan setelah desa ini defenitif menjadi desa Kampung Adat, terbentuknya kampung adat akan membawa kebaikan kepada masyarakat kampung seperti dalam menentukan pimpinan tertinggi dalam kampung adat, tidak akan ada orang yang berasal dari luar. Pembentukan kampung adat ini ibarat mengukir papan sendiri, yang tidak akan mengganggu kepada papan orang lain. terbentuknya kampung adat akan menjadikan penghulu kampung hanya akan menjalankan pemerintahan (administrasi pemerintahan), sedangkan pemangku adat adat hanya akan menjalankan adat (kepala suku). Bapak H. Muslim juga mengungkapkan kritiknya terhadap pelaksanaan Perda Kabupaten Siak No. 02 Tahun 2015, dalam analisanya Beliau mengatakan bahwa Pemerintah Daerah Kabupaten Siak tidak serius untuk melaksanakan Perda Kampung adat ini.

Mengenai penggalian asal usul dan adat istiadat di Kampung Adat Sakai Bekalar, peneliti melakukan wawancara dengan Bapak (Mansur) selaku Kerani Kampung yang menyebutkan:

saat ini hanya tinggal beberapa orang saja masyarakat bersuku sakai, dan tujuan pemerintah daerah yang ingin menghidupkan kembali hukum dan adat istiadat, tampaknya belum dapat terelealisasi di Kampung Adat Sakai saat ini, disebabkan sejauh ini memang belum ada pengesahan terkait hukum adat yang ada di Kampung Adat Sakai Bekalar. sejak dirubahnya status desa menjadi kampung ini, yang tujuannya untuk menghidupkan kembali adat istiadat yang pernah berlaku pada masanya, sampai saat ini kita belum ada melakukan kegiatan apap-apa, baik itu mengenai kebudayaan seperti upacara adat sakai, meski saya bukan orang sakai. Padahal ini namanya sudah berubah menjadi Kampung Adat Sakai” (Wawancara, 25 Agustus 2018)

Peneliti juga melakukan wawancara dengan Bapak (L. Saputra) Yang mengungkapkan:

bagaimana mau menghidupkan kembali asal-usul dan adat istiadat di Kampung Sakai Bekalar, tokoh-tokoh adatnya sudah tidak tinggal disini lagi, orang-orang sakai sudah banyak yang pindah tempat tinggal, dan boleh dikatakan sudah tidak ada lagi, kalaupun yang tinggal disini, tidak mengetahui lagi seperti adat istiadat itu seperti dahulunya. (Wawancara, 25 Agustus 2018)

Dari paparan dan keterangan para informan penelitian diatas, dapat dijelaskan bahwa beberapa permasalahan pasca penetapan kampung adat melalui perda Kabupaten Siak No. 2 Tahun 2015. Permasalahan kevakuman yang terjadi diakibatkan tidak hanya terkait kode kampung adat yang belum dikeluarkan oleh kementerian dalam negeri tetapi juga peraturan daerah Provinsi yang sesuai diatur dialam Pasal 109 Undang-Undang No. 6 Tahun 2014 tentang Desa. Hal ini mengakibatkan Desa/Kampung yang telah ditetapkan menjadi Kampung Adat di Kabupaten Siak masih menggunakan format desa/kampung biasa sehingga belum berjalannya pemerintahan kampung adat sebagaimana asal usul adat isitiadat ataupun susunan aslinya. 


\section{Faktor Pengahambat Pelaksanaan Penyelenggaraan Pemerintahan Kampung Adat di Kabupaten Siak}

Dalam pelaksanaan hak asal usul dan adat istiadat dalam penyelenggaraan pemerintahan pada Kampung adat di Kabupaten Siak, dan secara spesifik pada lokasi penelitian, Kampung Adat Kampung Tengah, Kampung Adat Kuala Gasib, Kampung Adat Lubuk Jering, Kampung Adat Sakai Bekalar. Dari hasil temuan penelitian di 4 (empat) Kampung Adat tersebut, dalam penyelenggaraan pemerintahan belum berjalan sesuai dengan yang dimaksud asal usul dan adat istiadat, hal tesebut dikarenakan beberapa faktor penghambat dalam pelaksanaannya ialah Kekosongan Peraturan (Regulasi), Pudarnya Adat Istiadat dan Tokoh Adat di Masyarakat dan Eksistensi Kelembagaan adat di masing-masing Kampung Adat yang telah ditetapkan.

\section{Kesimpulan Dan Saran}

\section{a. Kesimpulan}

Penetepan kampung adat di Kabupaten Siak didasarkan pada Undang-undang Nomor 6 tahun 2014 tentang desa, dimana salah satu poinnya mengatur tentang penataan desa adat atau dengan nama lain. Penetapan pemerintahan kampung adat di Kabupaten siak, juga didasarkan pada aspek historis sistem pemerintahan kerajaan siak masa lampau, dari berbagai sistem pemerintahan kerajaan siak yang diterapkan salah satunya ialah sistem pemerintahan kampung. Dalam struktur pemerintahan kerajaan siak, diluar pemerintahan pusat juga mengatur sistem pemerintahan di daerah-daerah (district dan onderdistrict), daerah-daerah tersebut dibagi kedalam beberapa kampung-kampung, sebagai satuan pemerintahan terbawah yang dipimpin oleh kepala suku yang bergelar penghulu dan batin, dan penghulu tersebut juga dibantu oleh para pembantunya dalam sebuah struktur pemerintahan tersendiri.

Penetapan 8 (delapan) pemerintahan kampung adat di Kabupaten siak dari 122 desa/kampung, oleh pemerintah daerah Kabupaten Siak karena dipandang masing-masing kampung tersebut memiliki historis masing-masing, spirit pemerintah Kabupaten Siak mengeluarkan kebijakan perubahan status desa menjadi kampung, dan menetapkan 8 (delapan) pemerintahan kampung adat melalui Peraturan Daerah Nomor 2 Tahun 2015 ialah untuk memunculkan kembali nilai-nilai, asal usul, tradisi, adat istiadat yang dahulunya oleh masyarakat dipegang sebagai suatu sistem nilai untuk mengatur aktivitas kehidupan, khususnya sebagai dasar dan prinsip dalam penyelenggaraan pemerintahan, dan berpotensi untuk diangkat kembali dan dilestarikan di era perkembangan zaman saat sekarang ini.

Pelaksanaan hak asal usul dan adat istiadat dalam penyelenggaraan pemerintahan kampung adat khususnya di Kampung Adat Kampung tengah, kampung adat kuala gasib, kampung adat lubuk jering, kampung adat sakai bekalar, yang telah ditetapkan oleh pemerintah Kabupaten Siak, belum terlaksana sesuai dengan hukum adat dan susunan asli dalam penyelenggaraan pemerintahan, hal tersebut dikarenakan dalam proses kebijakan penetapannya belum dilakukan melalui identifikasi, kajian secara komprehensif oleh pemerintah (Pemerintah Provinsi Riau, Pemerintah Kabupaten Siak) dan lembaga adat atau lembaga lainnya yang sejenis, dalam menyusun bentuk rumusan model atau penataan kelembagaan yang sesuai dengan asal usul, adat istiadat yang pernah dipraktekkan pada zaman dahulu.

Pelaksanaan asal usul dan adat istiadat dalam penyelenggaraan pemerintahan mengalami kekurangan pengaturan (regulasi) lanjutan dalam mengatur teknis penyelenggaraan pemerintahan, sehingga hal ini menyebabkan terjadinya kevakuman penyelenggara pemerintahan secara definitif yang telah berlangsung selama kurang lebih 3 (tiga) tahun pasca berlakunya kebijakan penetapan pemerintahan kampung adat tersebut. Belum lengkapnya 
regulasi yang dimaksud untuk mengatur pelaksanaan penyelenggaraan pemerintahan kampung adat yang sesuai dengan asal usul atau adat istiadat ialah Paraturan Daerah (Perda) Provinsi Riau tentang pengaturan Susunan kelembagaan, pengisian jabatan, dan masa jabatan Kepala Kampung Adat berdasarkan hukum adat. kevakuman dalam penyelenggaraan pemerintahan kampung adat di Kabupaten Siak disebabkan secara administrasi dalam proses perubahan status menjadi kampung adat ialah karena kampung adat yang ditetapkan tersebut belum mendapatkan Nomor Registrasi dari Gubernur dan kode kampung adat dari Kementerian Dalam Negeri Republik Indonesia.

Faktor penghambat pelaksanaan hak asal usul dalam penyelenggaraan pemerintahan kampung adat di Kabupaten Siak adalah belum lengkapnya pengaturan (regulasi) untuk mengimplementasikan, belum maksimalnya pelibatan masyarakat dalam proses pembentukan perda kampung adat, kurangnya sosialisasi dalam persiapan penetapan kampung adat, maupun setelah peraturan daerah ditetapkan, sehingga menyebabkan minimnya pemahaman masyarakat terkait kelembagaan pemerintahan kampung adat, kajian yang komprehensif terkait kelembagaan pemerintahan kampung adat sesuai dengan asal usul, adat istiadat tidak lagi terpelihara dan dipedomani dalam aktivitas kehidupan masyarakat, yang dikarenakan sudah heterogennya penduduk pada wailayah kampung yang ditetapkan, tokoh-tokoh adat yang ada pada saat ini jumlah sangat sedikit yang masih hidup, bahkan pada kampung adat sakai bekalar, boleh dikatakan tokoh adatnya sudah tidak ada lagi, karena suku sakai sebagai penduduk asli kampung adat bekalar sudah berpindah domisili ke wilayah lain.

\section{b. Saran}

Berdasarkan hasil penelitian yang telah dibahas pada bab sebelumnya maka peneliti menayarankan hal-hal sebagai berikut :

1. Lembaga adat melayu kabupaten siak mapun lembaga adat melayu provinsi riau, agar dapat segera melakukan identifikasi dan kajian secara komprehensif terkait dengan asal usul dan adat istiadat 8 (delapan) kampung adat yang telah ditetapkan pemerintah kabupaten siak, sehingga dalam rancangan peraturan daerah provinsi riau terkait pengaturan susunan kelembagaan, pengisian jabatan dan masa jabatan kepala penghulu kampung adat berdasarkan hukum adat, ketika ditetapkan sesuai dengan hukum adat yang ada dimasingmasing kampung tersebut.

2. Pemerintah kabupaten siak melalui BPMPD agar dapat memaksimalkan pembinaan dan pemberdayaan kelembagaan pemerintahan, lembaga kemasyarakatan, lembaga adat, agar dapat mempercepat terwujudnya penyelenggaraan pemerintahan kampung adat berdasarkan kewenangan hak asal dan adat istiadat.

3. Diperlukan kerjasama, sinergisitas, komitmen, antara pemerintah provinsi, kabupaten, kecamatan, pemerintah kampung adat beserta lembaga-lembaga kemasyarakatan, lembaga adat untuk menggali kembali tradisi, adat istiadat, kebudayaan, dan peninggalan sejarah lainnya.

\section{REFERENSI}

Adhiharinalti. Eksistensi Hukum Adat Dalam Penyelenggaraan Pemerintahan Desa Di Bali. Jurnal RechtsVinding, Media Pembinaan Hukum Nasional, Vol. 1 No. 3, Desember 2012.

Agustina Panca. Upaya Pemerintah Kampung Adat Kuala Gasib Kecamatan Koto Gasib Kabupaten Siak dalam melestarikan adat istiadat. JOM FISIP Universitas Riau Vol. 4 No. 1 2017

Biglen \& Bogdan, 1998. Qualitative research Methodology. New York: Harper and Row 
Dodi Haryono (et al), 2016 Model Penataan Kelembagaan Pemerintahan Kampung Adat Di Kabupaten Siak., 2016. Alaf Riau; Pekanbaru.

Eko Sutoro, 2015. Regulasi Baru, Desa Baru, Ide, Misi, dan Semangat UU Desa. Kementerian Desa, Pembangunan Daerah Tertinggal, Dan transmigrasi republik Indonesia, Jakarta.

Firmanudin Agus. 2005. Tesis "Kajian Tentang Implementasi Kebijakan Otonomi Desa Berdasarkan Undang Undang Nomor 22 Tahun 1999 Ditinjau Dari Aspek Kelembagaan Dan Pembiayaan Pemerintahan Desa Di Kecamatan Cipari Kabupaten Cilacap". Pascasarjana Program Studi Ilmu Administrasi Publik Universitas Jenderal Soedirman Purwokerto.

Gie The Liang, 1993. Pertumbuhan Pemerintah Daerah di Negara Republik Indonesia, Jilid I Edisi Kedua. Gunung Agung. Jakarta.

Mukhtar. Eksistensi Kelembagaan Kampung Adat Tengah Kecamatan Mempura Kabupaten Siak. JOM FISIP Universitas Riau Vol. 4 No. 12017

Silahuddin, M. 2015. Buku 1 Kewenangan Desa dan Regulasi Desa, Kementerian Desa, Pembangunan Daerah Tertinggal, Dan Transmigrasi Republik Indonesia Jakarta.

Sugiyono, 2012. Metode Penelitian Kuantitatif, Kualitatif dan RD. Bandung, Alfabeta.

Zudan Arif Fakrulloh. Kedudukan dan Penetapan Desa dan Desa Adat Berdasarkan UndangUndang Nomor 6 Tahun 2014 Tentang Desa. Jurnal Hukum 'Inkracht', Volume I, Nomor 1, Nopember 2014 Program Pascasarjana Universitas Borobudur

\section{Peraturan Perundang-Undangan :}

Undang-Undang Dasar Negara Republik Indonesia Tahun 1945

Undang - Undang Republik Indonesia Nomor 6 Tahun 2014 Tentang Desa. 15 Januari 2014. Lembaran Negara Republik Indonesia Tahun 2014 Nomor 7. Jakarta.

Peraturan Pemerintah Republik Indonesia Nomor 43 Tahun 2014 Tentang Peraturan Pelaksanaan Undang-Undang Nomor 6 Tahun 2014 Tentang Desa. 30 Mei 2014. Lembaran Negara Republik Indonesia Tahun 2014 Nomor 123

Peraturan Pemerintah Republik Indonesia Nomor 47 Tahun 2015 Tentang Perubahan Atas Peraturan Pemerintah Nomor 43 Tahun 2014 Tentang Peraturan Pelaksanaan UndangUndang Nomor 6 Tahun 2014 Tentang Desa. 30 Juni 2015. Lembaran Negara Republik Indonesia Tahun 2015 Nomor 157

Peraturan Menteri Dalam Negeri Republik Indonesia Nomor 1 Tahun 2017 Tentang Penataan Desa. 3 Januari 2017. Berita Negara Republik Indonesia Tahun 2017 Nomor 155.

Peraturan Menteri Dalam Negeri Republik Indonesia Nomor 84 Tahun 2015 Tentang Susunan Organisasi Dan Tata Kerja Pemerintah Desa. 31 Desember 2015. Berita Negara Republik Indonesia Tahun 2016 Nomor 6

Peraturan Menteri Desa, Pembangunan Daerah Tertinggal, dan Transmigrasi Republik Indonesi Nomor 1 Tahun 2015 Tentang Pedoman Kewenangan Berdasarkan Hak Asal Usul dan Kewenangan Lokal Berskala Desa. 28 Junuari 2015. Berita Negara Republik Indonesia Tahun 2015 Nomor 158.

Peraturan Daerah Kabupaten Siak Nomor 1 Tahun 2015 Tentang Perubahan Penamaan Desa Menjadi Kampung. 15 Januari 2015. Lembaran Daerah Kabupaten Siak Tahun 2015 Nomor 1

Peraturan Daerah Kabupaten Siak Nomor 2 Tahun 2015 Tentang Penetapan Kampung Adat di Kabupaten Siak. 15 Januari 2015. Lembaran Daerah Kabupaten Siak Tahun 2015 Nomor 2

Profil Kampung Sakai Bekalar, 2017. 
Dokumen Permohonan Desa Adat, Pemerintah Desa Bekalar . 2014. 